\title{
Transfer Pricing as a Management Tool for Value Addition
}

\section{Chetana M. Soni}

Assistant Professor,

Dr. Ambedkar Institute of Management Studies and Research, Nagpur, Maharashtra, India.

CITATION: Soni, Chetana M. (2019), "Transfer Pricing as a Management Tool for Value Addition", MERC Global's International Journal of Management, Vol. 7, Issue 3, pp. 228-233.

ARTICLE HISTORY: Submitted: February 17, 2019, Revision received: April 05, 2019, Accepted: April 17, 2019

ARTICLE TYPE: Review paper

\begin{abstract}
In the globalised world, where the things change very fast the transfer pricing is one of the emerging issues for the MNC's. A rapid rise in business activities and changing business environments make it difficult to manage transfer pricing activities. Stringent norms of international trade and focus on transfer pricing regime may lead to cross border trade more difficult. Transfer pricing wings are beyond maximising income. It addresses the important methods of transfer pricing with its application, the evolution of transfer pricing in India, a mechanism to reduce transfer pricing disputes and various provisions for the same. This paper explores the transfer pricing as a management tool for value addition.
\end{abstract}

KEYWORDS: Transfer pricing, Methods, Provision, Mechanism.

\section{BIBLIOGRAPHY}

1. Baistrocchi, Eduardo and Roxan, Ian (2012), Resolving Transfer Pricing Disputes: A Global Analysis, Cambridge University Press.

2. Eccles, Robert G. (1983), "Control with Fairness in Transfer Pricing", Harvard Business Review.

3. Jarallah, Shaif M. (2012), Transfer Pricing Strategies: A Case Study of Japanese Multinationals, Lap Lambert Academic Publishing.

4. Shapiro, Benson P. and Jackson, Barbara B. (1978), "Industrial Pricing to Meet Customer Needs," Harvard Business Review, November-December, pp. 119.

5. Singh, S. P. and Bagchi, Amaresh (2002), Transfer Pricing and Regulations for India: Approvals and Alternatives, National Institute of Public Finance and Policy.

6. Turner, Geoff (2013), Transfer Pricing in International Business: A Management Tool for Adding Value, Business Expert Press.

7. United Nationas Pratical Manual on Transfer Pricing, Chapter 6, accessed March 15, 2019.

8. Vancil, Richard E. (1973), "What Kind of Management Control Do You Need?", Harvard Business Review, March-April, pp. 75. 